\title{
A trial of adenine arabinoside in genital herpes
}

\author{
A. L. Hilton, T. E. C. BUShell, D. WAller, AND JOY Blight \\ From the Departments of Venereology and Virology, Bristol Royal Infirmary
}

SUMMARY Twenty-four episodes of genital herpes in $22 \mathrm{men}$, all confirmed by virus isolation, were studied in a double blind trial. They were treated either with $3 \%$ adenine arabinoside (Ara-A) in petrolatum ointment base or with the base alone applied four times daily for one week. The lesions were counted and sketched on days 0,2 , and 7 . There was no demonstrable advantage to be gained from the use of Ara-A ointment. The results of the Papanicolaou smears and virus isolation agreed in the diagnosis of $75 \%$ of cases. The presence of continuing lesions or fresh ones in some patients after the acute phase of the initial or recurrent attack of herpes necessitates the man taking precautions on resuming sexual intercourse.

\section{Introduction}

There is a continuing need to study antiviral drugs that may inhibit or kill genital herpes simplex virus (HSV) Type 2. A primary infection in the male is usually painful and will last between two and three weeks or longer, whereas a recurrent attack is more likely to be relatively painless and transient, or to persist for less than two weeks. The female partner on the other hand can occasionally develop more extensive and painful lesions of the genitalia and if the cervix is affected there can be serious sequelae. Most experimental drugs so far investigated are purine and pyrimidine derivatives. Adenine arabinoside (vidarabine, Vira-A, Ara-A) is a purine nucleoside (9-B-D-arabinofuranosyladenine) which has been shown to be active against deoxyribonucleic acid (DNA) viruses, including members of the herpes group (Schabel, 1968). Its therapeutic effect in life-threatening DNA viral infections (Keeney and Buchanan, 1975), including those in immunosuppressed patients (Ch'ien et al., 1976), is being assessed and if drug toxicity occurs it appears to be dose related (Ross et al., 1976). Topical application in the treatment of herpetic infections of the eye has had encouraging results (Pavan-Langston et al., 1973; Coster et al., 1976).

Three per cent Ara-A in petrolatum ointment base was made available for evaluation in the treatment of genital herpes in the male. As all herpetic

Address for reprints: A. L. Hilton, Special Clinic, Level Three, Bristol Royal Infirmary Extension, Bristol BS2 8HW

Received for publication 25 July 1977 infections are subject to latency, chronicity and recurrence, a double blind randomised comparison with a petrolatum placebo was used, each preparation being administered for seven days.

\section{Patients and methods}

All patients were seen in the Department of Venereology, Bristol Royal Infirmary between August 1974 and October 1975 and only those thought likely to return for follow-up visits were included. Patients with other sexually transmitted diseases were excluded as were those with severe secondary infection, so there were few patients receiving other concurrent forms of treatment. Each patient was questioned about any history of genital ulcers, and on the duration of symptoms, including that of pain, in the present attack. At each visit the number and distribution of lesions, old or fresh, were sketched. After treatment it was sometimes necessary to estimate the number of lesions if these were old and had coalesced. The old lesions were described as having 'not changed', 'dried', 'scabbed', or 'healed'; old lesions were said to have healed when there was no visible abnormality or only a residual slight erythema. Most of the vesicles were therapeutically ruptured on the first visit so aiding later differentiation of fresh from old lesions. Routine darkground microscopical examination for Treponema pallidum was undertaken together with serological screening. Haematological and transaminase investigations and urine analysis were also carried out and patients were requested to return for re-investigation one month later. 
VIROLOGY

Dry swabs were used for collecting material for the culture of HSV from patients on their initial visit and on more than $80 \%$ of the subsequent attendances when ulcers or blisters were present. The cottonwool swabs were transported in $50 \%$ skimmed milk in saline (Clarke et al., 1964). Each specimen was inoculated into cultures of human embryo fibroblasts and Hep 2 cells on the day of receipt, except for specimens taken after routine laboratory hours which were processed the following day. The identity of the isolates was confirmed by neutralisation with specific herpes simplex antiserum and then Types 1 and 2 were differentiated by (a) the cytopathic effect in BHK-21 cells (Smith et al., 1973) and (b) the nature of the lesions produced on the chorioallantoic membrane of fertile hens' eggs when inspected at seven days (Parker and Banatvala, 1967). Papanicolaou smears were prepared from scrapings of the penile lesions with a coverslip when the patients first attended, and again from $40 \%$ of the lesions which were swabbed for virus isolation during the trial period. Each patient was supplied with either Ara-A or the vehicle ointment in a double blind randomised trial with instructions to apply the ointment four times daily for one week. No attempt was made to confirm that the ointment was regularly applied other than to request that used and unused tubes be returned at the end of treatment. After their first attendance patients were seen 48 hours later (day 2), at the end of the treatment (day 7), and at the end of the trial period (day 28).

\section{Results}

Thirty-one patients took part in the trial, contributing 34 episodes of herpes genitalis. Five patients had histories of some form of allergy, and nine had received local applications to the skin. One patient received metronidazole and another erythromycin for accompanying tonsillitis during the seven days of treatment. The clinical features and the results of investigations carried out on presentation are listed in Table 1. When efficacy of treatment was compared (Table 2), five episodes in each group were excluded either because the virus cultures were
Table 1 Positive findings at initial visit

\begin{tabular}{|c|c|c|}
\hline & \multicolumn{2}{|l|}{ Treatment } \\
\hline & $\begin{array}{l}\text { Ara- } A \text { (total }=17 \\
\text { episodes) }\end{array}$ & $\begin{array}{l}\begin{array}{l}\text { Placebo }(\text { total }=17 \\
\text { episodes }) \ddagger\end{array}\end{array}$ \\
\hline $\begin{array}{l}\text { Previous genital herpes } \\
\text { Confirmation by virus }\end{array}$ & 5 & 9 \\
\hline culture $†$ & 12 (11 Type 2) & 14 (all Type 2) \\
\hline $\begin{array}{l}\text { Papanicolaou smear } \\
\text { positive }\end{array}$ & $8^{*}$ & 11 \\
\hline Regional adenopathy & 11 & 7 \\
\hline $\begin{array}{l}\text { Secondary infection } \\
\text { Darkground } \\
\text { illuminated }\end{array}$ & 7 & 4 \\
\hline Treponema pallidum & $\mathbf{0}$ & $0^{*}$ \\
\hline
\end{tabular}

negative or because the patients were uncooperative, thus leaving 12 episodes to be assessed in each group. One patient appeared in both groups; he was first treated with the placebo and four months later with Ara-A. Another patient was seen twice in the placebo group with an interval of more than six months. Both patients had a history of previous herpes infection. The treatment groups were similar when compared for complaints of pain, duration of symptoms, and number of lesions. Ara-A was no better than the placebo ointment in healing the original ulcers or preventing fresh lesions or late recurrences (see Tables 2 and 3).

Table 3 confirms the well established facts that first attacks of herpes simplex virus infection are associated with a greater number of lesions and take longer to heal than recurrences. At the end of a week's treatment with either placebo or Ara-A, $56 \%$ of the recurrences had healed compared with only $20 \%$ of the first attacks. Fresh lesions were observed in some patients during the seven days of treatment, during the next three weeks of the trial, and in the subsequent months when patients returned to the department for further advice. HSV was isolated either on day 2 or day 7 in seven of ten cases using Ara-A and in eight of nine cases using the placebo ointment; in the remainder the ulcers had healed or were not sampled. There was reasonable correlation between the results of virus

Table 2 Response to treatment

\begin{tabular}{|c|c|c|c|c|c|c|c|}
\hline \multirow{3}{*}{ Treatment } & \multirow{3}{*}{ No. of patients } & \multicolumn{2}{|l|}{ Day 0} & \multirow{2}{*}{\multicolumn{2}{|c|}{$\frac{\text { Day } 2}{\text { No. of patients }}$}} & \multirow{2}{*}{\multicolumn{2}{|c|}{$\frac{\text { Day } 7}{\text { No. of patients }}$}} \\
\hline & & \multirow{2}{*}{$\begin{array}{l}\text { Patients with } \\
\text { pain }\end{array}$} & \multirow{2}{*}{$\begin{array}{l}\text { Duration of } \\
\text { symptoms } \\
\text { Mean no. (days) }\end{array}$} & & & & \\
\hline & & & & Lesions healed & New lesions & Lesions healed & New lesions \\
\hline $\begin{array}{l}\text { Ara-A } \\
\text { Placebo }\end{array}$ & $\begin{array}{l}12 \\
12\end{array}$ & $\begin{array}{l}9 \\
7\end{array}$ & $\begin{array}{l}6 \cdot 6 \\
4 \cdot 4\end{array}$ & $\begin{array}{l}0 \\
0\end{array}$ & $\begin{array}{l}2 \\
2\end{array}$ & $\begin{array}{l}4 \\
4\end{array}$ & $\begin{array}{l}2 \\
3\end{array}$ \\
\hline
\end{tabular}

*Twelve episodes in 11 patients, one patient later treated with Ara-A 
Table 3 The relationship of history of infection with results of treatment and new lesions

\begin{tabular}{|c|c|c|c|c|c|c|c|c|}
\hline \multirow{4}{*}{$\begin{array}{l}\text { Type of } \\
\text { infection }\end{array}$} & \multirow{4}{*}{ Treatment } & \multirow{4}{*}{$\begin{array}{l}\text { No. of } \\
\text { patients }\end{array}$} & & & \multicolumn{4}{|c|}{ No. of patients } \\
\hline & & & \multicolumn{2}{|c|}{ Mean total no. of lesions } & \multirow{3}{*}{$\begin{array}{l}\text { All lesions } \\
\text { healed } \\
\text { At day } 7\end{array}$} & \multicolumn{3}{|c|}{ With new lesions } \\
\hline & & & \multirow{2}{*}{$\begin{array}{l}\text { Before } \\
\text { treatment }\end{array}$} & \multirow{2}{*}{$\begin{array}{l}\text { After } \\
\text { treatment }\end{array}$} & & \multirow{2}{*}{$\begin{array}{l}\text { During } \\
\text { treatment }\end{array}$} & \multicolumn{2}{|c|}{ After treatment } \\
\hline & & & & & & & Day 7-28 & $>28$ days \\
\hline Recurrence & $\begin{array}{l}\text { Ara-A } \\
\text { Placebo }\end{array}$ & $\begin{array}{l}2 \\
7^{*}\end{array}$ & $\begin{array}{l}6 \cdot 5 \\
8\end{array}$ & $\begin{array}{l}0 \\
3 \cdot 6\end{array}$ & $\begin{array}{l}2 \\
3\end{array}$ & $\overline{3}$ & $\overline{3}$ & $\begin{array}{l}2 \\
2\end{array}$ \\
\hline Initial & $\begin{array}{l}\text { Ara-A } \\
\text { Placebo }\end{array}$ & $\begin{array}{r}10 \\
5\end{array}$ & $\begin{array}{l}15 \cdot 8 \\
16 \cdot 6\end{array}$ & $\begin{array}{l}7 \cdot 5 \\
8 \cdot 6\end{array}$ & $\begin{array}{l}2 \\
1\end{array}$ & $\begin{array}{l}4 \\
2\end{array}$ & $\begin{array}{l}1 \\
2\end{array}$ & $\begin{array}{l}2 \\
2\end{array}$ \\
\hline
\end{tabular}

* Seven episodes in 6 patients, one patient later treated with Ara-A

culture and Papanicolaou smear with agreement in $75 \%$ of 52 specimens, both being reported positive on 23 occasions and negative on 16 occasions. The cytology was positive three times when virus culture was negative and virus culture was positive 10 times when the smear was negative. The isolation of HSV was a more sensitive diagnostic technique than the smear, particularly when there were insufficient numbers of squames in which to look for the typical multinucleate giant cells.

There was no adverse reaction in any patient treated with Ara-A, but in the control group one patient reported excessive moisture of the treated area which could have been related to treatment. However, two episodes of skin rashes in the same group were thought not to be related to drugs. Haematological and transaminase results and urine analysis failed to indicate drug toxicity.

\section{Discussion}

This investigation revealed that Ara-A possesses no advantage over placebo. It did not shorten the length of an attack, prevent recurrences, or reduce the excretion of HSV in the treatment of genital herpes in the male.

Idoxuridine (IDU) was found to be insoluble in most solvents until dimethyl sulphoxide (DMSO) was used (MacCullum and Juel-Jensen, 1966). It is possible that the DMSO or another base may be identified which would allow the relatively insoluble Ara-A to penetrate the skin more effectively, but even then the virus in the nerve and sacral ganglia would presumably be left intact. Systemic treatment might be curative but the condition is not serious enough to warrant this route of administration except in rare instances.

Fresh lesions, some relatively painless and inconspicuous, were observed during the week of treatment and the next three weeks. A new female partner would have been at risk from such a patient who practised unprotected sexual intercourse unaware of his continuing infectivity. That some at least of these new lesions could be associated with the petrolatum base was well demonstrated by Adams et al., 1975. They used the same Ara-A and placebo ointments with similar results, but they also included a group of patients left untreated, none of whom developed any fresh lesions.

We are indebted to Professor David Montefiore, Dr A. E. Tinkler, and Dr David Evans for their advice in the preparation of this trial and to the staff of this department, especially Mr A. G. Martin, for their assistance. We wish to acknowledge the laboratory aid from our colleagues in the departments of biochemistry and haematology and the provision of the trial ointments by Parke-Davis.

References

Adams, H. G., Vontver, L. A., Alexander, E. R., Benson, E. A., Remington, M. L., and Holmes, K. K. (1975). Controlled evaluation of topical adenine arabinoside for treatment of genital herpes in men. Journal of the American Venereal Disease Association, 1, 150-154.

Ch'ien, L. T., Whitley, R. J., Alford, C. A. Jr, Galasso, G. J., and the Collaborative Study Group. (1976). Adenine arabinoside for therapy of herpes zoster in immunosuppressed patients: Preliminary results of a collaborative study. Journal of Infectious Diseases, 133, Supplement, A184-A191.

Clarke, S. K. R., Corner, B. D., Gambier, D. M., Macrae, J., and Peacock, D. B. (1964). Viruses associated with acute respiratory infections. British Medical Journal, 1, 1536-1539.

Coster, D. J., McKinnon, J. R., McGill, J. I., Jones, B. R., and Fraunfelder, F. T. (1976). Clinical evaluation of adenine arabinoside and trifluorothymidine in the treatment of corneal ulcers caused by herpes simplex virus. Journal of Infectious Diseases, 133, Supplement, A173-A177.

Keeney, R. E., and Buchanan, R. A. (1975). Clinical application of adenine arabinoside. Annals of the New York Academy of Sciences, 255, 185-189.

MacCullum, F. O., and Juel-Jensen, B. E. (1966). Herpes simplex virus skin infection in man treated with idoxuridine in dimethyl sulphoxide. Results of double-blind controlled trial. British Medical Journal, 2, 805-807.

Parker, J. D. J., and Banatvala, J. E. (1967). Herpes genitalis: Clinical and virological studies. British Journal of Venereal Diseases, 43, 212-216.

Pavan-Langston, D., Dohlman, C. H., Geary, P., and Sulzewski, D. H. (1973). Intraocular penetration of Ara-A and IDU-therapeutic implications in clinical herpetic uveitis. Transactions of the American Academy of Ophthalmology and Otolaryngology, 77, 445-466.

Ross, A. H., Julia, A., and Balakrishnan, C. (1976). Toxicity of adenine arabinoside in humans. Journal of Infectious Diseases, 133, Supplement, A192-A198.

Schabel, F. M. (1968). The antiviral activity of 9-B-D-arabinofuranosyladenine (Ara-A). Chemotherapy, 13, 321-338.

Smith, I. W., Peutherer, J. F., and Robertson, D. H. H. (1973). Characterisation of genital strains of Herpesvirus hominis. British Journal of Venereal Diseases, 49, 385-390. 